\title{
THE INFLUENCE OF TEACHERS COMPETENCE AND ORGANIZATIONAL CLIMATE ON TEACHERS OF ENGLISH PERFORMANCE
}

\author{
Astri Riance \\ Universitas Bina Insani Lubuklinggau \\ Livero.humairah@yahoo.com \\ Submit, 24-11-2019 Accepted, 23-12-2019 Publish, 23-12-2019
}

\begin{abstract}
The objective of this study was to determine the effect of teachers competence and organizational climate on teacher of English performance at Senior High School in Lubuklinggau. This research used quantitative research method. Based on the result of data analysis and discussion, it can be concluded that 1) There was an influence of teachers' competence on teachers of English performance at Senior High School in Lubuklinggau it can be seen from the value of $t=6.608$ greater than the value of $t$ table (1.991) with a significant level of sig $=0.05,2)$ There was an influence of the organizational climate on teacher of English performance at Senior High School in Lubuklinggau it can be seen from the value of $t=4.197$ is greater than the value of $t$ table (1.991) with a significant level sig $=0.005,3$ ) There was an influence of teacher competence and organizational climate on Teacher of English performance at Senior High School in Lubuklinggau. It can be seen from the value of $\mathrm{F}$ count obtained $11.901>\mathrm{F}$ table $=2.33$ and significant level simultaneously sig F was 0.000 . From this result it can be concluded that there was significant influence of teachers competence and organizational climate on teachers of English performance at Senior High School in Lubuklinggau.
\end{abstract}

Keywords: teacher competence, organizational climate, teacher performance

\section{INTRODUCTION}

English is an important subject in educational, because English as foreign language, second language and international language, therefore many students must mastering English effectively. To reach this goal of course it must have a plan to create a conducive learning atmosphere and learning process so that students can actively develop their potential with the aim that students have a holistic personality.

Discussing about teachers performance will not be separated from factors that can affect a person's performance. Teacher competence and Organizational Climate are part of the factors that can affect teachers' performance. Problems of Teacher competence and Organizational Climate that is not conducive can result in low performance of existing teachers in education. 
Teacher competence is generally defined as skills and abilities. In the context of human resource, management, teachers' competence refers to the attributes or characteristics of a person making him successful at work. As stated by Sedarmayanti (2017) teacher competence is a fundamental characteristic possessed by someone who has direct influence on, or can predict, excellent performance.

From the statement above, it can be concluded that teacher competence include knowledge, skills and abilities that a teacher should be able to do in carrying out his work. and can be realized in real situation that can be useful for themselves and environment.

Considering the problems that exist at Senior High School in Lubuklinggau regarding on teacher competencies, there is still a lack of expertise in carrying out their work, lack of competence test for teacher, lack of seminars for improve teachers competence And the lack of teachers ability in managing the time in completing their assignments.

In an organization a teacher must be supported by the organizational climate especially from the leadership, the role of teacher competence and the application of the organizational climate of the leadership are very closely related to employee performance. This role must be able to provide leadership feedback in advancing the organization. According to Gibson et al. (1995) Stating that Organizational Climate is the nature of the work environment or physical environment in the organization that is felt by workers or members of the organization and is considered to be able to influence workers' attitudes and behavior towards their work.

Each person will feel the conditions that bring them to a perception about whether the environment where they live is accordance with their planning. If the environmental conditions of the organization grow with good cooperation between personnel, It can be created a conducive condition in the organization, this conditions is called the organizational climate. Climate cannot be touched but it exists like a rotating of air and influencing the events of an organization. Understanding of the organizational climate are expected to create a comfortable atmosphere for the teacher, in order to it will motivate teachers to improve the quality of teaching, and subsequently will produce good education quality.

There are 9 Senior high schools in Lubuklinggau, based on the observation which conducted by the researcher, The researcher found that, there was not conducive situation. When teacher lack of support to improve their knowledge and competence, lack of cooperation between teachers, and lack of freedom for doing an action in making adjustments for the tasks assigned. This factor can influence the teacher performance, as we know teacher is an educator 
with some duties and responsibilities who must have good performance to teach their students. The level of human resources in Indonesia will begin from development of education. It can be concluded that the success of education is largely determined by teacher performance.

Therefore there are many researches related to teachers performance as a way to improve the quality of teacher performance in Indonesia. Like the research conducted by Isbahi (2013) From the results of the research conducted it was concluded that work motivation and organizational climate simultaneously had a positive and significant effect on the performance of teachers of Public Elementary Schools. Research conducted by Septia (2016) concluded that teacher competence (pedagogical competence, personality competency, social competence, and professional competence) had a significant effect on teacher performance.

An International reasearch conducted by Kumar (2018) from his research was found that, there is significant impact of organizational climate on social dimension of teacher effectiveness of secondary schools. An international research conducted by Alam (2018) analyses of the results reveal that organizational climate of the school is significantly related to teacher effectiveness.

Different with the previous research the research conducted by the researcher was conduct to see wheather there was a significant influence on teacher competence and organizational climate on teacher performance. This research is different from previous research studies, because this study examines 3 variables with two influencing variables.

\section{LITERATURE RIVEW}

\section{Teacher Performance}

A person's performance is associated with routine tasks they do. For example, as a teacher, the routine task is to carry out the teaching and learning process at school. The optimal results achieved from the teaching assignments are the performance. The performance is the result of interaction or the functioning of motivational, ability, and perception elements. Galton and Simon,

Performance evaluation is a way to measure the contributions of individual members of the organization to the organization; the goal is to upgrade previous performance and motivate future performance improvements. Performance evaluation is carried out to provide an assessment of work results or work achievements obtained by organizations, teams or individuals (Krisma, 2017)

The good performance can be seen from teachers who attend at school and diligent in teaching, teachers teach seriously using lesson plans, teachers teach with enthusiasm and pleasure, use methods that vary according to subject matter, 
conduct teaching evaluations and follow up on the results of the evaluation using information technology and teacher welfare was achieved (Hidayatullah, 2018)

\section{Teacher Competence}

A professional teachers must have academic qualification and competencies. The competencies that a teacher must have namely pedagogical competence, personal competence, social competence and professional competence, the Regulation of the Minister of National Education of the Republic of Indonesia No. 16/2007. Those competencies are integrated with teacher performance. As an ideal teacher, she or he musthave a good qualification, professional and master the four teacher's competence.

\section{Definition of Organizational Climate}

The explanation of the concept of organizational climate, in fact, indicates and affirms that the organizational climate is a characteristic or special thing that a formal organization has, including a school organization that can differentiate formal organization of one institution with formal organization in another. Specifically, the facilities or tools, the level of education and work competence of organization members, the work member commitments of the organization, the level of welfare assurance obtained by each organization member, the arrangement of tasks and decision-making systems within the organization, the perception of each member of the organization a situation or circumstance and to the formation of behavior of every organization member and so forth (Gemnafle, 2016)

\section{RESEARCH METHOD}

The research procedures, in this study are as follows: 1) formulate problems that will be raised in research, by identifying problems, limiting problems and formulating problems, 2) establish research objectives so that this research does not extend to other discussions and focus on what is examined, 3) look for theoretical material from experts who support this research and look for references from relevant research, 4) determine the research methodology to be carried out by determining the type of research, research variables of time and place of research, population and samples, data sources, data collection techniques to be used as well as data analysis techniques needed in this study.

According to Sujarweni (2015) data collection techniques are data conducted by researchers to reveal or capture quantitative information from respondents according to the scope of research, here are some commonly used research data collection techniques as follows: 
1. Observation is a systematic observation and recording of symptoms that appear on the object of research in this research observation is done by observe Senior High School in Lubuklinggau

2. Questionnaire is a data collection technique that is done by giving a set of questions or written statements to the respondents to be answered. In this case the respondents are all teacher of Senior High School in Lubuklinggau.

In this study the measurement method uses a Likert scale measurement technique, each variable uses a Likert scale, where the Likert scale is used to measure the attitudes, opinions, and perceptions of a person or group of people about social phenomena and determine the focus of research, selecting informants as sources of data, collecting data, interpreting data and making conclusions on its findings Sugiyono (2016), on this measurement scale has a judgment score between 1 to 5 , which can be seen from the following table:

Table 1 Measurement Scale andScore

\begin{tabular}{ccc}
\hline Measurement Scale & Explanation & Score \\
\hline SS & Strongly agree & 5 \\
S & Agree & 4 \\
RR & Doubt & 3 \\
TS & Not agree & 2 \\
STS & Strongly Disagree & 1 \\
\hline
\end{tabular}

The research instrument used in this study was in the form of a Likert scale that contained 3 variables, namely Competency, organizational climate and performance. The Likert scale contains 48 questions consisting of 15 questions about teacherscompetence, 18 questions about organizational climate, and 15 questions about teachers performance. Data analysis activities include data processing and data presentation, performing calculations to describe data and testing hypotheses using statistical tests. The statistical tests used in this study are simple linear regression test, correlation coefficient test, $t$ test, multiple linear regression test, determination coefficient test and $\mathrm{F}$ test. The explanation is as follows

\section{FINDINGS}

\section{Simple Linear Test Results Teacher Competency Variable on Performance}

Simple linear regression test is used to determine the effect of Teacher Competence on the Teachers of English Performance at Senior High School in Lubuklinggau. This test have done by SPSS program version 20.0 will be used. The detailed test results will be presented in the table below: 
Table 2 Simple Linear Regression Results

\begin{tabular}{lccc} 
& \multicolumn{3}{c}{ Coefficients $^{\mathbf{a}}$} \\
\hline \multirow{2}{*}{ Model } & \multicolumn{2}{c}{ Unstandardized Coefficients } & Standardized Coefficients \\
\cline { 2 - 4 } 1 (Constant) & 57.840 & Std. Error & Beta \\
Teachers Competence & .572 & 7.605 & .398 \\
\hline
\end{tabular}

Source : data result 2019 by using SPSS 19

From the recapitulation results of the simple linear regression table 7 above, the regression equation for estimating the dependent variable using the independent variable is as follows: $\mathrm{Y}=57,840+0.572 \mathrm{X} 1$

From the estimation equation the regression function above shows that the constant value obtained is equal to $\mathrm{a}=57,840$. This shows that without being influenced by the independent variable Teacher Competence (X1), the Performance (Y) is equal to 57,840 units. The regression coefficient value represents the Teacher Competency variable obtained by b1 $=0.572$, indicating that each one-time change in Teacher Competency, the Performance will change directly proportional, that is equal to 0.572 units.

\section{Simple Linear Test Results of Organizational Climate Variables on Performance}

Simple linear regression test was used to determine the effect of Organizational Climate teachers of English performanceat Senior high school in Lubuklinggau.

Table 3 Simple Regression Linier Result

\section{Coefficients}

\begin{tabular}{llccc}
\hline & & \multicolumn{2}{c}{ Unstandardized Coefficients } & Standardized Coefficients \\
\cline { 3 - 5 } Model & & B & Std. Error & Beta \\
\hline 1 & (Constant) & 47.985 & 12.098 & .491 \\
& Organizational Climate & .694 & .562 & \\
\hline
\end{tabular}


Coefficients

\begin{tabular}{llccc}
\hline & & \multicolumn{2}{c}{ Unstandardized Coefficients } & Standardized Coefficients \\
\cline { 3 - 5 } Model & & B & Std. Error & Beta \\
\hline 1 & (Constant) & 47.985 & 12.098 & .491 \\
& Organizational Climate & .694 & .562 & \\
\hline
\end{tabular}

From the recapitulation results of the simple linear regression table 4.63 above, the regression equation for estimating the dependent variable using all independent variables is as follows: $\mathrm{Y}=47,985+0,694 \mathrm{X} 2$

From the estimation equation the regression function above shows that the constant value obtained is equal to $\mathrm{a}=47,985$. This shows that without being influenced by the independent variable Organizational Climate (X), the Performance (Y) amounted to 47,985 units. The regression coefficient value represents the variable Organizational Climate obtained by b2 $=0.694$, indicating that every change in one Organizational Climate, the Performance will change directly proportional, that is equal to 0.694 units.

\section{Coefficient Correlation Test}

Correlation Coefficient Test Results Teacher Competency Variables on Performance. To measure the percentage contribution of the independent variable and the dependent variable, the magnitude of the correlation coefficient is measured with the following results

Table 4 Coefficient Correlation (R)

\begin{tabular}{llrrrr}
\multicolumn{4}{c}{ Model Summary } & \\
\hline Model & $\mathrm{R}$ & R Square & $\begin{array}{c}\text { Adjusted R } \\
\text { Square }\end{array}$ & $\begin{array}{c}\text { Std. Error of the } \\
\text { Estimate }\end{array}$ \\
\hline 1 & $.798^{\mathrm{a}}$ & .610 & .516 & 3.49954 \\
\hline
\end{tabular}

Source: data result 2019 by usingSPSS 19

Table 4 above shows the value of the correlation coefficient $(\mathrm{R})$ the independent variable Teacher Competence (X1) obtained, amounting to 0.610. This can be interpreted that the relationship between the independent variables Teacher Competency (X1) to the dependent variable Performance (Y) partially strong can be said. 


\section{Correlation Coefficient Test Results Organizational Climate Variables on Teachers Performance}

To measure the percentage contribution of the independent variable and the dependent variable as a whole, the magnitude of the correlation coefficient is measured with the following results:

Table 5 Coefficient Correlation (R)

Model Summary

\begin{tabular}{|c|c|c|c|c|}
\hline Model & $\mathrm{R}$ & R Square & $\begin{array}{l}\text { Adjusted } \\
\text { Square }\end{array}$ & $\begin{array}{l}\mathrm{R} \text { Std. Error of } \\
\text { the Estimate }\end{array}$ \\
\hline 1 & $.791^{\mathrm{a}}$ & .636 & .511 & 3.45204 \\
\hline
\end{tabular}

Source : Data Result 2019 by using SPSS 19

The value of the correlation coefficient $(\mathrm{R})$ of the independent variable Organizational Climate (X2) obtained, amounted to 0.791 . This can be interpreted that the relationship between the Organization Climate (X2) independent variable and the Performance dependent variable (Y) partially can be said to be strong.

\section{T Test Results for Correlation Teacher of English Competency Variables on Teachers Performance}

To see the partial effect of each independent variable on the dependent variable can be explained using the $t$ test, detailed results of the $t$ test are presented in the table below:

Table 6 T Test (Partial

Coefficients $^{\mathrm{a}}$

\begin{tabular}{|c|c|c|c|c|c|c|}
\hline \multirow{2}{*}{\multicolumn{2}{|c|}{ Model }} & \multicolumn{2}{|c|}{$\begin{array}{c}\text { Unstandardized } \\
\text { Coefficients }\end{array}$} & \multirow{2}{*}{$\begin{array}{c}\text { Standardized } \\
\text { Coefficients } \\
\text { Beta } \\
\end{array}$} & \multirow[t]{2}{*}{$\mathrm{t}$} & \multirow[t]{2}{*}{ Sig. } \\
\hline & & B & Std. Error & & & \\
\hline \multirow[b]{2}{*}{1} & (Constant) & 57.840 & 7.605 & & 7.605 & .000 \\
\hline & $\begin{array}{l}\text { Teacher } \\
\text { Competence }\end{array}$ & .572 & .419 & .398 & 6.608 & .004 \\
\hline
\end{tabular}

Source : Data Result 2019 by using SPSS 19

Based on the results of the test calculation table 11 above can be explained, that the Teacher Competency Variable (X1) on Performance (Y) shows the value of $t=6.608$ is greater than the value of table (1.991) with a significance level of sig $=0.05$. This means that partially the Teacher Competency variable (X1) has an influence on the Performance (Y) of the teacher of English at Senior High School Lubuklinggau 


\section{T Test Results Correlation of Organizational Climate Variables on Teachers Performance}

To see the partial effect of each independent variable on the dependent variable can be explained using the $t$ test, detailed results of the $t$ test are presented in the table below:

\begin{tabular}{llrrrrr}
\multicolumn{7}{c}{ Table 7 T test (Partial) } \\
Coefficients
\end{tabular}

Source : Data Result 2019 by using SPSS 19

Based on the results of the $t$ test calculation of table 4.68 above, it can be explained that the Organizational Climate Variable (X2) on Performance (Y) shows the value of tcount $=4.197$ is greater than the value of table (1.991) with a significance level of $\operatorname{sig}=0.005$. This means that partially the Organizational Climate variable (X2) has an influence on the performance $(Y)$ teachers of at Senior High School inLubuklinggau.

\section{Multiple Linear Regression Test}

Multiple linear regression test was used to determine the effect of the primary data tested, which came from 2 independent variables namely the effect of Teacher Competence and Organizational Climate on teacher of English Performance at Senior High School in Lubuklinggau. In this test statistical software tools will be used with SPSS version 20.0. The detailed test results will be presented in the table below:

Table 8 Multiple Linier Regression

Coefficients $^{\text {a }}$

\begin{tabular}{|c|c|c|c|c|c|}
\hline \multirow[t]{2}{*}{ Model } & \multicolumn{2}{|c|}{$\begin{array}{c}\text { Unstandardized } \\
\text { Coefficients } \\
\end{array}$} & \multirow{2}{*}{$\frac{\begin{array}{c}\text { Standardized } \\
\text { Coefficients }\end{array}}{\text { Beta }}$} & \multirow[t]{2}{*}{$\mathrm{t}$} & \multirow[t]{2}{*}{ Sig. } \\
\hline & B & Std. Error & & & \\
\hline (Constant) & 43.168 & 14.421 & & 7.993 & .000 \\
\hline $\begin{array}{l}\text { Teacher } \\
1 \text { competence }\end{array}$ & .596 & .464 & .492 & 3.195 & .004 \\
\hline $\begin{array}{l}\text { Organizational } \\
\text { Climate }\end{array}$ & .574 & .318 & .301 & 3.626 & .003 \\
\hline
\end{tabular}

Source : Data Result 2019 by using SPSS 19 
From the recapitulation results of the multiple linear regression above, the regression equation for estimating the dependent variable using all independent variables is as follows: $\mathrm{Y}=43,168+0.596 \mathrm{X} 1+0.574 \mathrm{X} 2$. The results of the multiple linear regression test show that

1. The value (constant) shows a value of 43,168 units meaning that if the value of the independent variable (Teacher Competence and Organizational Climate) is zero then the dependent variable value (Performance) is 43,168 units in this case if the independent variable rises or influences in one unit, the independent variable will rise or be fulfilled.

2. Value of the regression coefficient variable Teacher Competence (X1) to the Performance variable $(\mathrm{Y})$ of $\mathrm{b} 1=0.596$ units means that if Teacher Competency (X1) has increased by one unit, it will experience an increase in Performance of 0.596 units.

3. The value of the regression coefficient of variable Organizational Climate (X2) on Performance $(\mathrm{Y})$ of $\mathrm{b} 2=0.574$ units means that if the Organizational Climate (X2) increases by one unit, it will experience an increase in Performance of 0.574 units.

\section{Determination Coefficient Test}

Table 9 Determination Test

\begin{tabular}{|c|c|c|c|c|}
\hline \multicolumn{5}{|c|}{ Model Summary } \\
\hline Model & $\mathrm{R}$ & R Square & Adjusted R & Std. Error of the \\
\hline & & & Square & Estimate \\
\hline 1 & $.715^{\mathrm{a}}$ & .746 & .605 & 3.48000 \\
\hline
\end{tabular}

a. Predictors: (Constant), Teachers Competence, Organizational Climate

The value of determinant coefficient $(\mathrm{R} 2 \neg$ ) obtained, amounting to 0.715 , can be interpreted that the variation in the change value of the dependent variable (Performance) can be explained by all independent variables (Teacher Competency and Organizational Climate) together (simultaneously) by $71.5 \%$ and the remaining $28.5 \%$ is influenced by other variables. 
F Test

Table 10 F Test(Simultanious)

ANOVA $^{\mathrm{a}}$

\begin{tabular}{rlrrrrr}
\hline Model & & \multicolumn{1}{c}{$\begin{array}{c}\text { Sum of } \\
\text { Squares }\end{array}$} & df & \multicolumn{1}{c}{$\begin{array}{c}\text { Mean } \\
\text { Square }\end{array}$} & F & Sig. \\
\hline \multirow{3}{*}{1} & Regression & 21.816 & 2 & 10.908 & 11.901 & $.003^{\mathrm{a}}$ \\
& Residual & 448.084 & 37 & 12.110 & & \\
& Total & 469.900 & 39 & & & \\
\hline
\end{tabular}

a. Dependent Variable: Performance

b. Predictors: (Constant), Teachers Competence, Organization Climate Source Data SPPS 2019

Simultaneous / simultaneous test (F test) was conducted to see the effect of the independent variables on the dependent variable. Based on the recapitulation of the results of multiple linear regression tests, it was found that the Fcount value obtained was 11.901> Ftable $=2.33$ and the significance level simultaneously sig $\mathrm{F}$ was 0,000 . It shows that in together (simultaneously) the independent variables of research (Teacher Competence and Organizational Climate) have a significant influence on the dependent variable (Performance). The simultaneous/ simultaneous test results (F-test) also prove that the third hypothesis of this study, namely Teacher Competence and Organizational Climate, influences teachers of English performance at Senior High school in Lubuklinggau.

\section{DISCUSSION}

\section{The Effect of Teachers Competence on English of Teachers Performance}

Teacher competence refers to performance and rational actions to meet certain specifications in the implementation of educational tasks. Said to be rational because it has direction and purpose, while performance is a real behavior in the sense that it can not only be observed but includes something invisible. Competence is a major component of professional standards in addition to a code of ethics as a regulation of professional behavior specified in certain procedures and supervision systems (Mulyasa, 2007).

From this statement can be known that there is a corellation between competence and performance. Performance is a good goals fof good competence. Therefore in this research the researcher try to know the correlation between teachers competence and teachers performance by using some test as follows:

Simple linear regression test which used to determine the effect Teacher Competence on the teachers of English Performance at Senior High School in Lubuklinggau. From the recapitulation results of simple linear regression $\mathrm{Y}=$ $57.840+0.572 \mathrm{X} 1$. From the estimation equation the regression function above 
shows that the constant value obtained is equal to $\mathrm{a}=57,840$. This shows that without being influenced by the independent variable Teacher Competency (X1), the Performance $(\mathrm{Y})$ is equal to 57,840 units. The regression coefficient value represents the variable Teacher Competence obtained by b1 $=0.572$, indicating that every change in one unit in Teacher Competency, the Performance will change directly proportional, which is equal to 0.572 units.

To measure the percentage contribution of the independent variable and the dependent variable as a whole, the magnitude of the correlation coefficient is measured. The value of the correlation coefficient $(\mathrm{R})$ of the independent variable Teacher Competence (X1) obtained, is equal to 0.610. It can be interpreted that the relationship between the independent variables Teacher Competency (X1) to the Performance dependent variable (Y) partially can be said to be strong. To see the partial effect of each independent variable on the dependent variable can be explained using the $t$ test.

$\mathrm{T}$ test was used to know the influence of competence on teachers performance. From the calculations can be explained, that the Teachers performance greater than the value of the table (1.991) with a significance level of $\operatorname{sig}=0.05$. It means that partially the Teacher Competency variable (X1) has an influence on the teachers of English performance at Senior High School Lubuklinggau Ha is accepted and Ho is rejected.

\section{The Effect of Organizational Climate on Teacher Performance}

Teachers job performance defined as duties performed by a teacher at a particular period in the school system in achieving organizational goals (Obilade, 1999). There are a few reasons contributing to low level of teacher's job performance such as inadequate pay, poor career structure, lack of promotion opprotunities, poor school facilities, inadequate school disciplinary policy (Badenhost, 2008)

Healthy organizational climate could enhance teacher's Job performance Selamat (2013). From some theories above can be concluded that a good organizational climate is very important for teachers performance. There was a correlation between organizational climate and teachers performancce. Because an healty organizational climate can improve the teachers performance. Therefore in this study the researcher try to find the effect organizational climate on teachers performance by using the following test: simple linear regression test was used to determine the effect of Organizational Climate on English Teachers Performance at Senior High School in Lubuklinggau.. From the recapitulation results of simple linear regression $\mathrm{Y}=47,985+0,694 \mathrm{X} 2$. From the estimation equation the regression function above shows that the constant value obtained is equal to $\mathrm{a}=$ 47,985. This shows that without being influenced by the independent variable 
Organizational Climate (X), the Performance (Y) is 47,985 units. The regression coefficient value represents the variable Organizational Climate obtained by b2 $=$ 0.694, indicating that every change in one Organizational Climate, the Performance will change directly proportional, that is equal to 0.694 units ..

To measure the percentage of the contribution of the independent variable and the dependent variable as a whole. The value of the correlation coefficient $(\mathrm{R})$ of the independent variable Organizational Climate (X2) obtained, amounted to 0.791. It can be interpreted that the relationship between the Organization Climate (X2) independent variable and the Performance dependent variable (Y) partially can be said to be strong.

To see the partial effect of each independent variable on the dependent variable can be explained using the $t$ test. Based on the results of the $t$ test calculation, it is explained that the Organizational Climate Variable (X2) on Performance $(\mathrm{Y})$ shows the value of tcount $=4.197$ is greater than the value of table (1.991) with a significance level of sig. $=0.005$. It means that partially the Organizational Climate variable (X2) has an influence on teacher performance (Y) $\mathrm{Ha}$ is accepted and Ho is rejected.

\section{The Effects of Teacher Competence and Organizational Climate on Teachers of English Performance}

According to Dwivedi (Iskandar, 2016) there are factors that affect a person's performance including internal factors and external factors or environmental factors. Internal factors come from within the worker, while external or environmental factors.

Factors affecting employee performance according to Wibowo (2014) include internal factors including: the ability of individual talents and interests of a person, as well as external factors which include: organizational support components consisting of training and development, equipment and technology, organizational climate, performance standards, and management and co-workers.

According to Michael Zwell (Wibowo, 2014) said that there are several factors that influence employee competence including beliefs and values, skills, experience, personality characteristics, motivation, emotional issues and organizational climate.

According to Wibowo (2014) states that competence is an individual characteristic that underlies the performance of employees in the workplace. According to Glimer (Mulyadi, 2015) that the climate of an organization or subunit has a character that influences the results achieved by a management.

From some theories above can be known that there is a corellation between motivation and organizational climate on performance. Therefore in this research 
the writer try to find the effect of competence and organizational climate on teacher performance by the following tests:

Multiple linear regression test was used to determine the effect of the primary data tested, which came from 2 independent variables, namely the effect of Teacher Competence and Organizational Climate on English of Teachers performance at Senior High School in Lubuklinggau.

From the recapitulation results of multiple linear regression $\mathrm{Y}=43.168+$ $0.596 \mathrm{X} 1+0.574 \mathrm{X} 2$. The results of the multiple linear regression test show that a) the value (constant) shows a value of 43,168 units means that if the value of the independent variable (Teacher Competence and Organizational Climate) is zero then the dependent variable value (Performance) is 43,168 units in this case if the independent variable rises or influences in one unit, then the independent variable will rise or be fulfilled. b) Value of the regression coefficient variable Teacher Competency (X1) to Performance variable (Y) of b1 $=0.596$ units means that if Teacher Competency (X1) has increased by one unit, it will experience an increase in Performance of 0.596 units. c) The regression coefficient value of the Organizational Climate variable (X2) to Performance (Y) of b2 $=0.574$ units means that if the Organizational Climate (X2) increases by one unit, it will experience an increase in Performance of 0.574 units

The value of the determinant coefficient $(\mathrm{R} 2 \neg)$ obtained, amounting to 0.715 , can be interpreted that the variation in changes in the value of the dependent variable (Performance) can be explained by all independent variables (Teacher Competence and Organizational Climate) together (simultaneously) by $58.20 \%$ and the remaining $41.80 \%$ is influenced by other variables.

In addition to seeing the effect of the independent variables on the dependent variable jointly carried out simultaneous / simultaneous tests ( $F$ test). Where based on the recapitulation of the results of multiple linear regression tests, it was found that the calculated $\mathrm{F}$ value was $11.901>$ Ftable $=2.33$ and the significance level simultaneously sig $\mathrm{F}$ was 0.000 . This shows that together (simultaneously) the independent variables of research (Teacher Competence and Organizational Climate) have a significant influence on the dependent variable (Performance). The simultaneous / simultaneous test results (F-test) also prove that the third hypothesis of this study, namely Teacher Competence and Organizational Climate, influences the Teachers of English performance at Senior High School in Lubuklinggau 


\section{CONCLUSION}

There was an influence of teacher competence on teacher of English performance, there is an influence of the organizational climate on English of teachers performance, there is an influence of teacher competence and organizational climate on Teachers of English performance

\section{REFERENCES}

Alam, M. (2018). Study of Organizational Climate in Relation to Teacher Effectiveness of Secondary School Teachhers. International Journal of Informative and Futuristic Research. IJIVR/V6/E3/008

Badenhorst, C. (2008). Dissertation writing: A research journey. Pretoria: Van Schaik

Faliqul I \& Maulana. (2013). Pengaruh Motivasi Kerja dan Iklim Organisasi Terhadap Kinerja Guru SD Negeri Se Kecamatan Rembang Kabupaten Rembang. Jurnal Hanata Widya. 2 (5). 3-5

Gemnafle, M. Simon, P.,W. \& John, R.,B. (2016). Organizational Climateof The School and Teacher Performance Improvment in the 21th Century. IJSR Journal. 79-57

Gibson. (1995). Organisasi dan Manajemen, Edisi ke empat, Jakarta : Erlangga.

Hidayatulah, R. (2018). Relationship Between Teacher Profesionals Competences and Teacher Work Autonomy. Journal Pendidikan. 1 (2)

Iskandar, J. (2016). Prilaku Manusia Dalam Kelompok dan Organisasi. Bandung: Puspaga.

Kumar, P. (2018). Impact of Organizational Climate on Academic, Profesional, and Social Dimensions of Teacher Effectiveness on Secondary School DOI Journal. 10. 13140

Mulyadi. (2015). Prilaku Organisasi dan Kepemimpinan Pelayanan. Bandung: Alfabeta.

Mulyasa., E. (2007). Standar Kompetensi dan Sertifikasi Guru. Bandung: Remana Rosda Karya.

Obilade, S.O.(1999). Leadership qualities and styles as they relate to Instructional Productivity. The Manager Department of Educational Management, University of Ibadan, 5(1): 25-32.

Sedarmayanti. (2017). Sumber Daya Manusia dan Produktivitasnya. Bandung: Mandar Maju.

Selamat, N. (2013). The Impact of Organizational Climate on Teacher' Job Performance. Article January 2013

Septia, K. (2016). Pengaruh Kompetensi dan Kinerja Guru SMP Negeri 6 Singaraja, Jurnal Program Study Pendidikan Ekonomi (JPPE). 7 (2)

S Krisma, S. (2017) Belajar dan Faktor Faktor yang Mempengaruhinya. Jakarta: Rineka Cipta

Sugiyono. (2015). StatistikPenelitian. Cetakan Ke Dua Puluh Tujuh.Bandung: Alfabeta.cv. Bandung 
2019. Linguistics, English Education and Art (LEEA) Journal 3 (1):92-107

(2016). Penelitian Kuantitatif, Kualitatif dan $R$ \& D. Bandung: Alfabeta.CV. Bandung.

Sujarweni, W. (2015). Metodelogi Penelitian Bisnis\& Ekonomi . Yogyakarta: Pustakabarupress.

Wibowo. (2014). Manajemen Kinerja. Jakarta: Raja Grafindo Persada 